\title{
ALCOA \#1 (41AN87): A Frankston Phase Settlement along Mound Prairie Creek, Anderson County, Texas
}

Clyde Amick

Unknown

Ed Furman

Timothy K. Perttula

Heritage Research Center, Stephen F. Austin State University

James E. Bruseth

Bonnie C. Yates

Follow this and additional works at: https://scholarworks.sfasu.edu/ita

Part of the American Material Culture Commons, Archaeological Anthropology Commons, Environmental Studies Commons, Other American Studies Commons, Other Arts and Humanities Commons, Other History of Art, Architecture, and Archaeology Commons, and the United States History Commons

Tell us how this article helped you.

This Article is brought to you for free and open access by the Center for Regional Heritage Research at SFA ScholarWorks. It has been accepted for inclusion in Index of Texas Archaeology: Open Access Gray Literature from the Lone Star State by an authorized editor of SFA ScholarWorks. For more information, please contact cdsscholarworks@sfasu.edu. 


\section{ALCOA \#1 (41AN87): A Frankston Phase Settlement along Mound Prairie Creek, Anderson County, Texas}

\section{Creative Commons License}

\section{(c) (1) (8)}

This work is licensed under a Creative Commons Attribution-NonCommercial 4.0 International License 


\title{
Caddoan Archeology
}

\section{ALCOA \#1 (41AN87): A Frankston Phase Settlement along Mound Prairie Creek, Anderson County, Texas}

\author{
Clyde Amick, Ed Furman, Timothy K. Perttula, James E. Bruseth, and Bonnie C. Yates
}

The ALCOA \#1 (41AN87) site is a Frankston Phase (ca. A.D. 1400-1650) site located on a high alluvial terrace of Mound Prairie Creek, about seven kilometers northeast of Palestine, Texas. Mound Prairie Creek, a perennial stream, flows southeast to east across the county and drains into the Neches River. The site is approximately 10 meters above the Mound Prairie Creek floodplain, and the creek channel is 300 meters to the south.

Although the investigations at the site have been rather limited to date, it appears that the ALCOA \#1 site is a single component Frankston Phase homestead, or possibly a small hamlet (see Story and Creel 1982:30-33). Other Frankston phase sites are known on Mound Prairie Creek, Hurricane Creek, Walnut Creek, and Brushy Creek, all Neches River tributaries, and the possibility exists that these may be part of a larger related Caddo community and settlement system.

In area, the site may cover 0.5 to 1 acre. Habitation debris has been found scattered on the crest of the landform, but is particularly concentrated in a trash midden deposit on the slope of the terrace (Figure 1). The trash midden deposits are about 100 square meters in area and between 60 and $70 \mathrm{~cm}$ in thickness. Faunal and floral remains are well preserved in the trash midden, and large ceramic sherds, burned clay nodules, and ash concentrations are found throughout the deposit.

A caretaker at the ALCOA Aluminum Plant discovered the site, which is thickly wooded with pines and hardwoods, a few years ago. This individual carried out uncontrolled digging in a midden area, churning approximately four square meters of deposits while looking for whole ceramic vessels; no records were apparently kept of these diggings. Amick, Furman, and Dr. Jacklyn Bass, concerned avocational archaeologists from the Palestine area, were able to relocate the site. They took it upon themselves to learn more about the site, and in 1989 initiated their own investigations at ALCOA \#1. Proper notes and records have been maintained throughout the work to document the horizontal and vertical provenience of the cultural remains, and the dirt from the midden excavations has been screened through quarter-inch mesh. All ceramic, lithic, and faunal remains recovered from these excavations have been retained, including lithic debris, fire-cracked rocks, burned clay, and identifiable/unidentifiable faunal remains, and are under detailed study by the authors at this time.

Because of the integrity of the site, and the excellent preservation of faunal remains from a Late Caddoan Period component, Bruseth and Perttula visited the site with the two senior authors in August 1990. The purpose of the visit was two-fold: (a) to gather datable samples of charcoal from controlled contexts in the midden, and (b) obtain a large and representative sample of preserved faunal and floral remains from the deposit. These types of data, which are critical for addressing important regional research questions concerning chronology, settlement patterns, and subsistence (Story 1990:320), are almost totally lacking for the Late Caddoan archaeological record in the Neches River Basin (see Story 1990: Table 83 and Figure 54; Perttula 1991: Appendix V). 


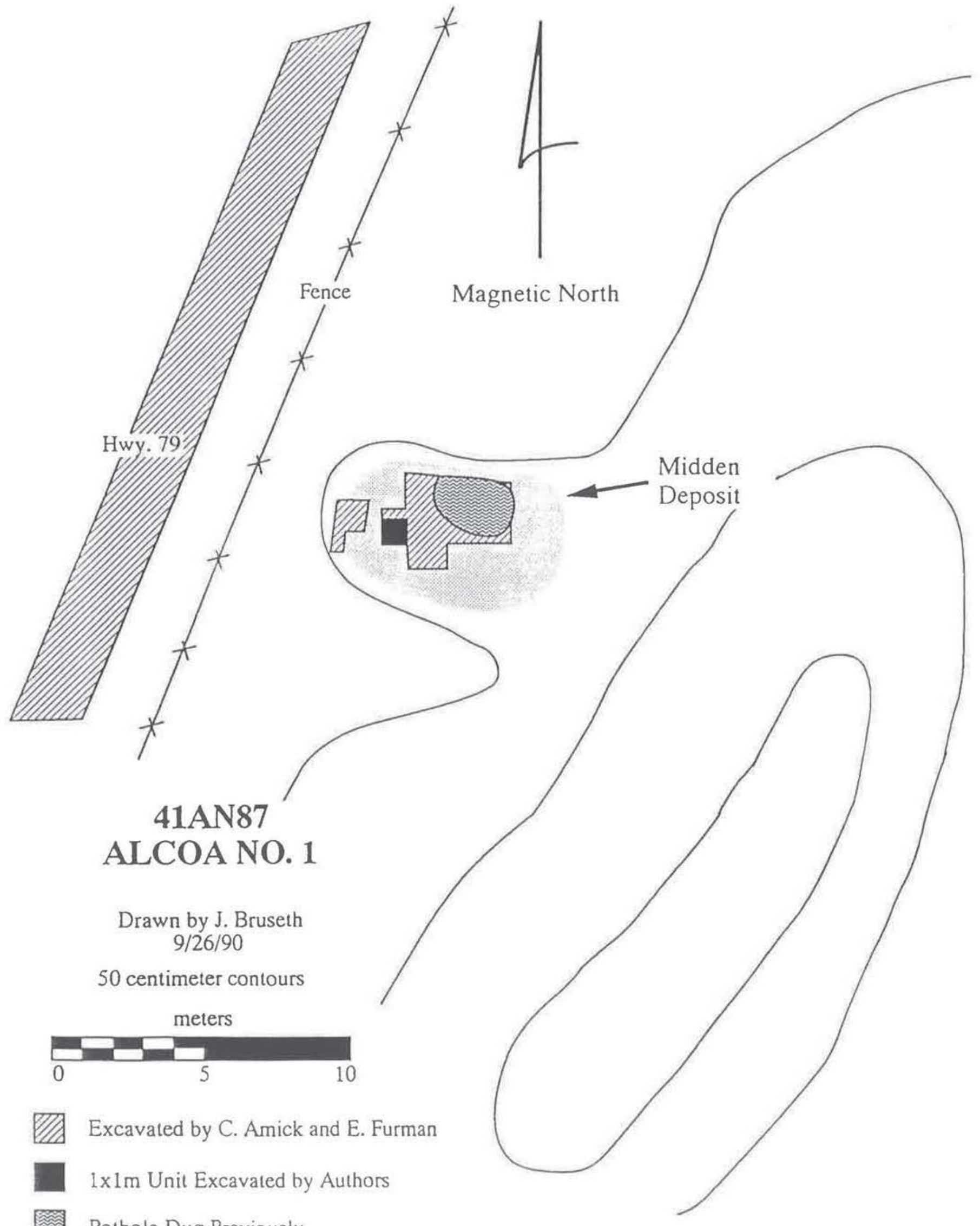




\section{Caddoan Archeology}

The authors, with the assistance of Dr. Bass, excavated a $1 \times 1$ meter square in the midden adjacent to the midden excavations opened earlier by the two senior authors. The area was selected because of the known thickness of the midden, and on preliminary assessments of the density of cultural materials across the midden based on the previous work. The $1 \times 1$ meter square was excavated in 10 centimeter thick levels, and screened through quarter-inch mesh. Approximately 25 percent of each of the seven levels was screened through nested sixteenth-inch and quarter-inch mesh to aid in the recovery of small faunal remains and certain macrobotanical remains. Twenty liter flotation samples were also obtained from arbitrary levels $3-5(20-50 \mathrm{~cm}$ below surface) and 7 (60-70 cm below surface) in the midden.

The results of this recent work are discussed in the remainder of the paper. A more comprehensive presentation, incorporating the analysis of all materials recovered in the various investigations at the ALCOA \#1 site (and related sites in the vicinity), is in preparation.

Two radiocarbon samples of charred nutshell were submitted to Beta Analytic Inc. from levels $4(30-40 \mathrm{~cm})$ and $6(50-60 \mathrm{~cm})$ in the trash midden. The uncorrected radiocarbon dates are $490+/-60$ B.P. (Beta-43537) from level 4 and $550+/-60$ B.P. (Beta-43538) from the level 6 sample. The calibrated ages of the samples are A.D. 1406 and A.D. 1425, with calibrated date ranges of A.D. 1387-1426 from level 6 in the trash midden and A.D. 1403-1442 from level 4 (Stuiver and Becker 1986).

Over 900 ceramic sherds were recovered in the single $1 \times 1$ meter square excavated by the authors in the ALCOA \#1 trash midden. Amick and Furman have at least 1500 sherds from their excavations at the site; their collection has been photodocumented by Bruseth and Perttula, but it has not been thoroughly studied at this time. Between the two collections, over 510 sherds with surface decoration or treatment (i.e., brushing) have been identified.

As with other Frankston phase occupations in the Neches River Basin (e.g., Shafer 1981; Anderson et al. 1974), brushing is the most common ceramic surface treatment at the ALCOA \#1 site. Brushed sherds, including Bullard Brushed as well as brushed varieties of Maydelle Incised and LaRue Neck Banded, account for more than 46 percent of the sherds with any type of surface treatment. Poynor Engraved accounts for about 21.5 percent of the decorated sherds, followed by Maydelle Incised, Killough Pinched, and LaRue Neck Banded with between 4 and 19 percent of the sherds. These ceramic types are also well represented in nearby Frankston phase components.

The generally low frequency of brushed sherds in the ALCOA \#1 ceramic assemblage suggests that the occupation occurred primarily during the earlier part of the Frankston phase. This is supported by the two radiocarbon samples from the lower part of the trash midden.

It is interesting to note that brushed sherds in Frankston phase sites at Lake Palestine comprise between 46 and 84 percent of the decorated sherds; these are from assemblages with at least 290 decorated sherds. The latest Frankston phase sites are thought to have the highest frequencies of brushing (e.g., Kleinschmidt 1982). However, the frequency of brushing increases from 33-44 percent in the lower midden deposits $(30-63 \mathrm{~cm})$ to more than 60 percent in the upper midden deposits at ALCOA \#1. This may indicate that the trash midden deposits have some time depth, or that more than one Frankston phase component is represented at the site, and that it dates after ca. A.D. 1450. 


\section{Caddoan Archeology}

Ceramic pipes are usually quite common at local Frankston phase sites (cf. Anderson et al. 1974; Kleinschmidt 1982), and the ALCOA \#1 site is no exception. Pipe sherds ( $N=7)$ from elbow pipes were found throughout the trash midden, particularly in the top $30 \mathrm{~cm}$ of the deposit. None of the pipe sherds from the site have any decoration of them.

Burned clay pieces were abundant throughout the trash miden deposits; a total of 141 pieces were identified from the $1 \times 1$ meter square. Twenty burned clay pieces had grass and stick impressions from them being used as daub from a Caddoan structure, and two pieces

of a mud dauber nest were found between $40-50 \mathrm{~cm}$. Most $(\mathrm{N}=118)$ of the burned clay pieces lacked impressions of sticks or plants, and their function is unknown. A clay coil fragment, recovered from near the base of the midden, provides some evidence for the production of ceramics at the site.

Only a small amount of lithic artifacts have been recovered in the trash midden excavations. These lithics include one possible arrowpoint fragment from $20-30 \mathrm{~cm}$, one possible ferruiginous sandstone metate fragment from $10-20 \mathrm{~cm}$, five pieces of fire-cracked rock, and 26 pieces of lithic debris. The lithic debris is most common in the upper $30 \mathrm{~cm}$ of the deposit, and is dominated by local cherts and quartzites that were probably procured in upland gravels (e.g., Anderson 1971, 1972). Amick and Furman have recovered a single Perdiz arrowpoint from $16-30 \mathrm{~cm}$ below surface in their trash midden excavations.

A wide variety of faunal remains are preserved at the site, including several hundred identifiable fragments from the following species and genera: Gar sp., Catfish, Buffalofish, Frog sp., Box Turtle, Wild Turkey, medium and large birds of indeterminate species, a Raptor (cf. Buteo sp.), Opossum, Cottontail, Swamp rabbit, Fox or Gray Squirrel, Raccoon, White-Tailed Deer, and Bison. The faunal assemblage is dominated by White-Tailed Deer, which is typical for Late Caddoan Period samples in Northeast Texas. Bison is represented by only one element, which was recovered near the base of the midden. Although we know from ethnographic accounts that the East Texas Caddo hunted Bison in historic times, there is very little archaeological evidence available that documents the Caddoan use of this important animal species (Perttula 1990). None of the faunal samples from nearby Lake Palestine contained evidence of Bison use (Anderson et al. 1974).

\section{Summary}

The ALCOA \#1 site is a well-preserved Frankston phase settlement with abundant faunal and floral remains in a dense trash midden. The habitation area has not been investigated, and hopefully it can be protected (along with the remaining portions of the trash midden), either by State Archeological Landmark designation and/or site acquisition. The Archaeological Conservancy has expressed an interest in acquiring the property, and steps are under way to pursue this option.

\section{References}

Anderson, Keith M.

1971 Archeological Resources of Lake Palestine, Texas. Report submitted to the National Park service by the Department of Anthropology, Southern Methodist University, in partial fulfillment of Contract 14-10-7:931-37. 


\section{Caddoan Archeology}

Anderson, K.M.

1972 Prehistoric Settlement of the Upper Neches River. Bulletin of the Texas Archeological Society 43:121-197.

Anderson, Keith M., Kathleen Gilmore, Olin F. McCormick III, and E. Pierre Morenon 1974 Archaeological Investigations at Lake Palestine, Texas. Southern Methodist University, Contributions in Anthropology 11. Dallas.

Kleinschmidt, Ulrich K.W.

1982 Review and Analysis of the A.C. Saunders Site, 41AN19, Anderson County, Texas. Master's Thesis, Department of Anthropology, The University of Texas, Austin.

Perttula, Timothy K.

1990 The Development of Agricultural Subsistence, Regional and Diachronic Variability in Caddoan Subsistence, and Implications for the Caddoan Archaeological Record. Part II: Faunal and Paleobotanical Data from the Caddoan Area. MS on file, Department of Archeological Planning and Review, Texas Historical Commission, Austin.

1991 Historic Context: The Development of Agriculture in Northeast Texas before A.D. 1600. Manuscript on file, Texas Historical Commission, Department of Archeological Planning and Review, Austin.

Shafer, Harry J.

1981 Archeological Investigations at the Attaway Site, Henderson County, Texas. Bulletin of the Texas Archeological Society 52:147-178.

Story, Dee Ann

1990 Cultural History of the Native Americans. In The Archeology and Bioarcheology of the Gulf Coastal Plain, by Dee Ann Story, Janice A. Guy, Barbara A. Burnett, Martha Doty Freeman, Jerome C. Rose, D. Gentry Steele, Ben W. Olive, and Karl J. Reinhard, pp. 163-366. Arkansas Archeological Survey, Research Series No. 38. Fayetteville.

Story, Dee Ann and Darrell G. Creel

1982 The Cultural Setting. In The Deshazo Site, Nacogdoches County, Texas. Volume I: The Site, Its Setting, Investigation, Cultural Features, Artifacts of Non-Native Manufacture, and Subsistence Remains, edited by Dee Ann Story, pp. 20-34. Texas Antiquities Committee, Texas Antiquities Permit Series, No. 7. Austin.

Stuiver, Minze and Bernd Becker

1986 High-Precision Decadal Calibration of the Radiocarbon Time Scale, AD 1950-2500

BC. Radiocarbon, Volume 28 (No. 2B), pp. 863-910. 